\title{
Looking Back to Move Forward: Using History to Understand the Consensual Forest Management Model in the Terai, Nepal'
}

\section{Poshendra Satyal Pravat}

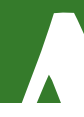

long struggle has been going on world-

wide between the state, local people and various stakeholders over the control, management and use of forest and land resources. In particular, in the history of many agrarian political economies of the developing world there have been conflicts over forest resources between local people and the state. An analysis of historical pat-

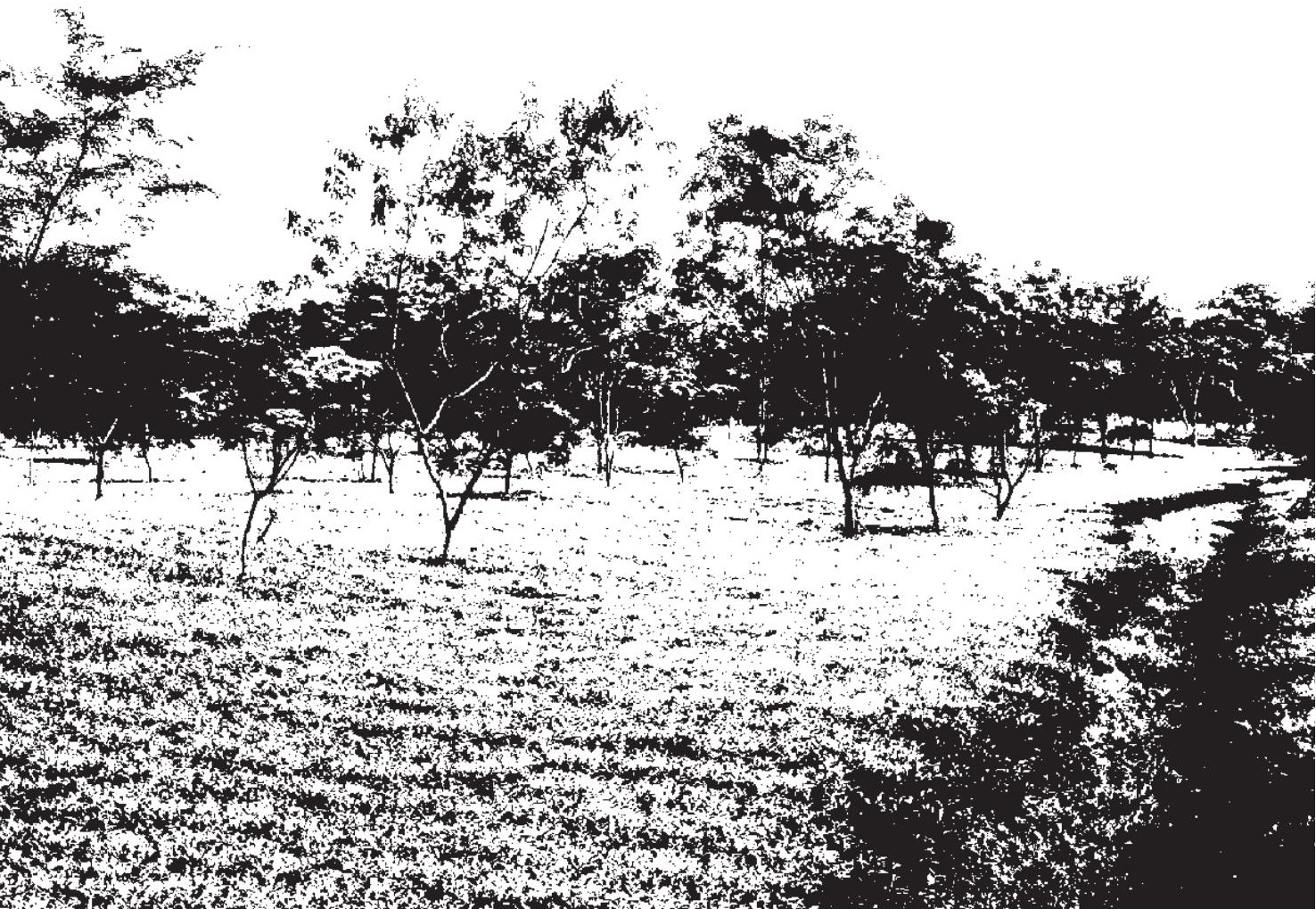


terns of annexation of forest and land by the state and the resultant struggles by local people against state takeover is fundamental to understand the emergence of various debates around global forest management. ${ }^{2}$ For most of the twentieth century, the dominant approach to conservation of forest and, in general, natural resources was to exclude people from 'natural' places and restrict access to, and use and control of, these places by local populations. In the later decades of the twentieth century, the role of powerful and centralised state agencies in forest management began to be questioned, and there were increasing calls for public involvement and participation (under different names and according to different models of forest management, such as participatory management, community forestry, co-management, collaborative management, joint forest management etc.). As a result, a variety of forest management policies and practices currently exist worldwide, sometimes in direct conflict with one another, at other times coexisting without friction. These policies and practices have been constantly rearticulated and transformed historically in response to wider changes in political, economic, social and natural environments. ${ }^{3}$ They have also had various impacts on forests, forest-dependent people, local users, and other stakeholders. Through the historical case of Terai forestry in Nepal,

${ }^{1}$ This paper is an offshoot of the author's doctoral thesis, which researched Terai forestry using an environmental justice framework (P. Satyal Pravat, Understanding Environmental Justice in the Developing World: The Case of Forest Management Policy and Practice in the Terai, Nepal, PhD Thesis, The Open University, Milton Keynes 2009). The paper draws from a combination of secondary sources, the author's own experience of working in the agriculture and forestry sector in Nepal, and two empirical field trips in Nepal (November 2006-February 2007 and July-August 2007) involving both informal interactions and formal interviews with a range of Terai forestry stakeholders. Feedback to earlier drafts was provided by David Humphreys and Joe Smith of The Open University. The paper also benefitted from the comments of John Dargavel and two other anonymous referees.

${ }^{2}$ M. Doornbos, A. Saith, B. White, "Forest Lives and Struggles: An Introduction", in Forests: Nature, People and Power, M. Doornos, A. Saith, B. White (eds), Blackwell Publishers, Oxford 2000, pp. 1-10.

${ }^{3}$ O. Springate-Baginski, P. Blaikie, Forests, People and Power: The Political Ecology of Reform in South Asia, Earthscan Publiations, London 2007, p. 2. 
this paper examines the impacts of past policies and politics, and the underlying conflicts of interest between stakeholders, particularly the state and local people.

Considerable debate and increasing conflict exists in Nepal today between the government and community forestry activists over the issue of who should manage the Terai forests in the southern plains. Most forest areas in the Terai are state-controlled, although active dayto-day forest management is usually lacking. The government has shown a deep reluctance to hand over the Terai forests for community management as demanded by community forestry activists. A series of other attempts to bring the Terai forests under alternative management plans (such as the collaborative model advocated by the government, which consists of a joint partnership with the local stakeholders) have been largely ineffective. ${ }^{4}$ As a result, Terai forestry exhibits a state of confusion and stalemate in terms of forest management policy and practice. Given the contemporary context of a changing political landscape in Nepal, with, on the one hand, an allegiance between the main political parties and the Maoists and, on the other, the ethnic struggle of the Madhesis ('people of the plains'), who demand more political rights in the Terai, it is time to initiate a dialogue among the various stakeholders of Terai forestry on how to get out of this deadlock and find a transparent, accountable and consensual form of forest governance. ${ }^{5}$ In this context it might be useful to step back and examine how past politics and policy have historically affected the forests, local people and the interactions between them in the Terai.

${ }^{4}$ Although both community forestry and collaborative forest management are forms of participatory forest management, there are important differences between them. In the latter model there is a decreased level of participation of local users and restricted access to and control of revenues from forests, compared to full control and 100 per cent benefits to local users in the former. These differences are at the root of the disagreements on how Terai forests should be managed in Nepal.

${ }^{5}$ Since 2006, Nepal has gone through a number of radical changes in the political landscape, most notably the peace agreement between the Maoist rebels and the government (2006), the election of a Constituent Assembly to write a new constitution, the formation of a new coalition government of major political parties, and the declaration of a federal republic following the end of the monarchy (all in 2008). 
Adopting an approach to history as 'dialogue between the past and present', this paper attempts to provide a brief history of forest politics in the Terai focussing on the role of the state and its rulers in equity and ecological issues. ${ }^{6} \mathrm{I}$ argue that Terai forestry has historically been an inequitable domain that principally benefited the state and ruling classes, with ordinary Nepali people not receiving a fair share of the benefits from forest management. My review of the socio-political and environmental history of the Terai also suggests that concern for environmental conservation was not a priority until recently, as the earlier governments were more interested in exploiting the area's high-value forests for commercial purposes. The historical role of the state in the control of the Terai forests is a major legacy that continues to influence contemporary forestry policy and practice in the region. This, I argue, helps to explain the reluctance of the forest bureaucracy to adopt transparent and accountable forest governance in the Terai, as well as the state's policy of restricting the handover of Terai forests for community or more decentralised forms of participatory forest governance to only a small part of the forests.

While in the hills of Nepal local forest user groups have been successful in preserving forests through well-established community forestry practices, there exist conflicts over the management of the Terai forests, arising from differences in view between donors, Nepalese environment and development non-governmental organizations (NGOs), community forestry activists, and the government. The main challenges for sustainable Terai forestry have been supporting the creation of new institutions for forest management, addressing increased user group heterogeneity and inequity, complicated resource-settlement patterns that raise equity issues for distant users (mainly Madhesis), the existence of large high-value forests, and the proximity to the timber market in India, which stimulates a lucrative trade in illegal timber.

If managed efficiently, it is argued, the Terai forests could not

${ }^{6}$ The approach of exploring past policy and politics in order to understand contemporary issues in Nepal was developed by a noted Nepali historian, the late Mahesh Chandra Regmi. See M.C. Regmi, Landownership in Nepal, Adroit Publishers, Delhi 1977. 
only boost the local and national economies but also assist in environment conservation. ${ }^{7}$ However, given the historical context of inequitable and ecologically unsustainable forestry practices in the Terai, which continue to shape current forest politics and policy in the region, the question of how equity and ecological issues can be addressed remains important. In the new political situation in Nepal, after years of instability and conflict, with its emphasis on equity, inclusive democracy and state restructuring, and in the context of the existing logjam in Terai forest governance, it is timely to ask: Why and how should Terai forestry be restructured and democratised? Who benefits from Terai forestry, and how? Who - or what - loses, and why? To answer these questions and guide future actions it is important first of all to examine Terai forestry in an historical context. Hence in this paper I provide a brief historical overview of forestry policy and practice in the Terai which, I argue, could offer some valuable lessons for the present problems of forest governance in the region. Before reviewing past forest politics, including a brief look at the environmental and socio-political history of the Terai, I give a brief introduction to the region and then move on to discuss its socio-economic heterogeneity and inequity.

\section{The Terai}

The name Terai or Tarai refers to the southern lowlands of Nepal (see Figure 1). This region consists of an extension into Nepal of the Gangetic plains of northern India (generally referred as the outer Terai) and the river valleys located between the Siwalik (Chure) and Mahabharat ranges (the inner Terai). The region extends from east to west along the entire length of Nepal. The southern part of the Terai (outer Terai), bordering on India, is mostly under agriculture and

${ }^{7}$ In fact, in 1999, the World Bank estimated that the annual profits from timber production in the Terai could value around US $\$ 160$ million in addition to the environmental benefits from the forests, if they were managed properly. I. Hill, Forest Management in Nepal, World Bank Technical Paper N. 445, World Bank, Washington DC 1999. 
densely populated (mainly by Madhesis), whereas the forested northern part (inner Terai), known as the Bhabhar, has a lower population density (of Pahadiyas, that is, people of hill origin). While the Terai covers roughly only about one-fifth of the total area of Nepal, almost half of the Nepalese population lives in the region today. ${ }^{8}$

Unlike the sparse and low-value forests in the hills, Terai forests are high-value and productive. The continuous stretch of dense forests extending along the Terai from east to west was popularly known as Char Koshe Jhadi (roughly translatable as 'Four-Mile Strip'), and is one of the few remains of the vast forest resources that previously existed in the region. According to the latest available data on forest cover, the Terai plains now include about $4,873 \mathrm{~km}^{2}$ of forestlands outside national parks and wildlife reserves, the dominant species being highvalue hardwoods such as Sal (Shorea robusta) (43 per cent of total stem volume). A single mature Sal tree may fetch US \$ 1000 or more.

In addition to high-value forests, the Terai is also considered to be the grain basket of Nepal, having higher agricultural productivity than anywhere else in the country. Rice, jute, sugar cane, mustard, tobacco, herbs and spices are the main agricultural products. The Terai's agricultural surplus, particularly its surplus of rice (the staple food of most Nepalese), not only supports the food deficit hill regions of Nepal but is also exported to India (both legally and illegally). Thus the importance of the Terai for the Nepalese economy is significant. However, increasing migration from the hills and from India and the resulting pressure of agricultural expansion on forestland have hindered the capacity of the Terai to make a sustainable contribution both to the economy and to the environment.

\section{Unequal citizens in an unequal region: socio- economic heterogeneity and inequity in the Terai}

To understand the social and ecological implications of the history

${ }^{8}$ Nepal Government, National Census-2001, Central Bureau of Statistics, Kathmandu 2001.

9 Winrock International, Emerging Issues in Community Forestry in Nepal, Winrock International, Kathmandu 2002. 


\section{Fig 1. Map of Nepal showing the Terai region in the south}

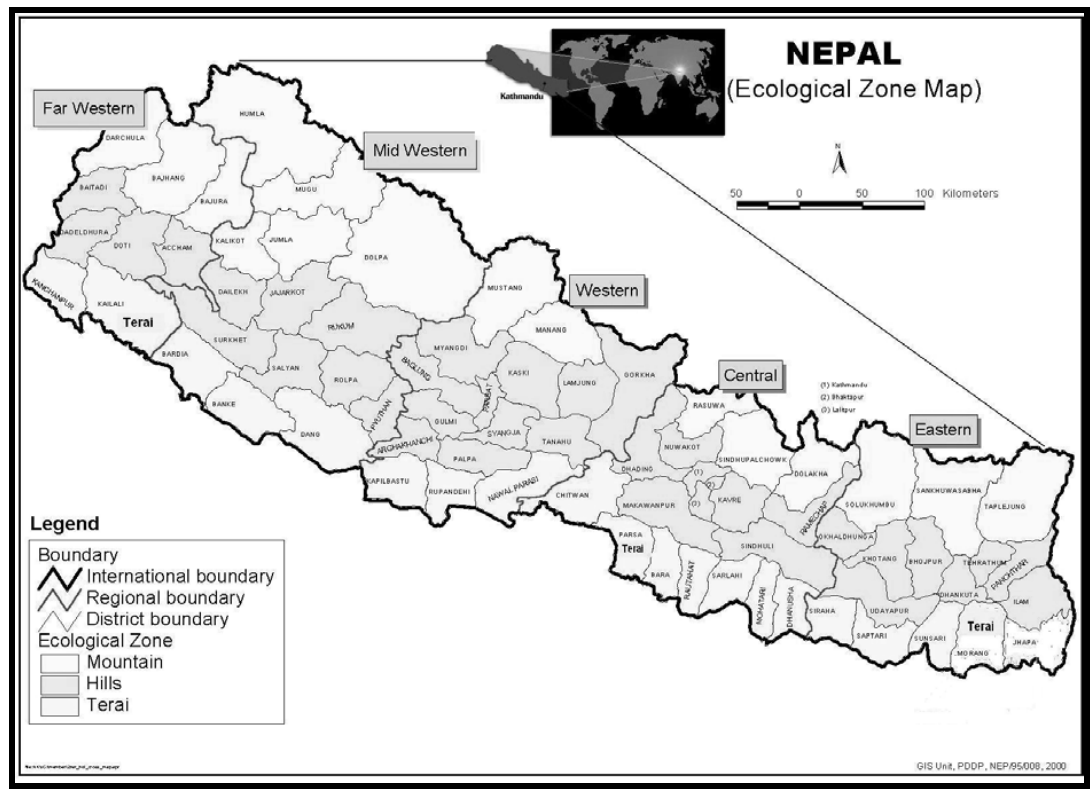

Source: adapted from www.undp.org.np (accessed 24 January 2011).

of forest politics in the Terai, it is essential to first understand the heterogeneous nature of Terai society and the resultant conflicts of interests and power imbalances between a number of very diverse groups. In general, the inequities in Terai society reflect inequalities and differences prevalent in the social and spatial structure of Nepalese society, which is highly stratified in terms of class, income, caste and ethnicity, gender, religion and culture. Although in Nepal there are over 103 castes and ethnic groups, at least 92 different languages or dialects, and more than ten different religions, ${ }^{10} \mathrm{Nepal}$ remained the sole Hindu kingdom until 2007, when the Interim Constitution made it a secular state.

Traditionally, people from the top two castes based on Hindu hierarchy - Brahmins and Chhetriyas - shared power with the ruling monarchs and have largely dominated and benefited from the state

${ }^{10}$ Nepal Government, Statistical Pocket Book 2004, Central Bureau of Statistics, Kathmandu 2004. 
bureaucracy since the proclamation of the state of Nepal in 1768 . The feudal or semi-feudal nature of Nepalese society - involving privilege, patronage, the domination of particular classes in sociopolitical life and the perpetuation of regional and ethnic inequality and gender and caste discrimination - has further aggravated inequitable power relations. ${ }^{11}$

The composition of Terai society is complex. There are some indigenous groups - mainly Tharus - and increasing migrants from the hills of Nepal and from India. Except for the hill migrants ( $\mathrm{Pa}$ hadiyas), the people of the Terai are commonly known as Madhesis. Their ancestors established themselves in the Terai in remote times and share languages and cultures with the Madhesis living south of the Nepal-India border. The caste Hindus from India, of Indo-Aryan origin, are believed to have started migrating to the region at the end of the second millennium BC, preferably to the foothills on the northern edge of the Terai, probably because it was easier to clear forest for agriculture there than in areas closer to the Ganges in India. ${ }^{12}$

Although Madhesis are often regarded as a single group, they include caste Hindus (with Dalits at the bottom of caste hierarchy), Muslim minorities, and various tribal groups, including the original inhabitants, the Tharus (who have, however, recently characterized themselves as non-Madhesis). The Tharus were the main original inhabitants of the Terai. They were forest-dwellers and made their living as huntersgatherers, and had some immunity to aulo, a virulent form of malaria that plagued the region until the 1950s. When increasing numbers of migrants bought, or sometimes illegally seized, large tracts of valuable agricultural land, the Tharus became the minority in most places and are now marginalised and severely disadvantaged in many ways.

Historically, and even today in public discourse, Madhesis have been considered outsiders in Nepal. They are excluded from many spheres of national life. As will become clear later in this paper, the Nepali sense of common national identity has largely been identi-

${ }^{11}$ World Bank, DFID, Unequal Citizens: Gender, Caste and Ethnic Exclusion in Nepal-Summary, World Bank, DFID, Kathmandu 2006.

${ }^{12} \mathrm{~J}$. Whelpton, A History of Nepal, Cambridge University Press, Cambridge 2005, p. 14. 
fied with the hills rather than the Terai. Furthermore, in the past the state's rhetoric and portrayal of Nepali nationalism as being based on the dominance of the Nepali language and loyalty to the ruling elites mainly benefited hill Brahmins and Chhetriyas, who shared common cultural characteristics, spoke the same language and were generally loyal to successive rulers. This form of Nepali nationalism excluded the people of Terai, most of whom spoke languages other than Nepali (mainly Awadhi, Bhojpuri and Maithili, the latter being spoken by the largest number of speakers in Nepal after Nepali itself) and had close links with North Indian culture. The worst form of exclusion for many Madhesis was the continuous apathy and neglect of successive Nepalese governments with regard to the citizenship problem.

Among the inhabitants of the Terai, only a handful of those who were successful in forging alliances with the ruling elites benefited from the Nepali state. The wealthiest Tharus and Madhesis with political connections across Nepal and the neighbouring Indian states of Bihar and Uttar Pradesh felt relatively secure, whereas ordinary Tharu and Madhesi peasants were merely preoccupied with day-today economic survival.

Although the Terai people were neglected at the national level, the region as such still received some benefits from the state. Its gentle morphology, contrasting with the steep hills and rugged mountains of Nepal, allowed the construction of extensive road networks and other facilities and services such as electricity, telephone, and tube wells (mainly in the eastern Terai). The region has hence witnessed impressive growth, despite the Kathmandu-centric overall development patterns in Nepal. However, rural-urban income inequality is generally worse in the Terai than elsewhere. Due to a biased state development policy concentrating on Kathmandu and the eastern region while neglecting the west (mainly the unprivileged Karnali region), the western Terai districts suffer from severe inequalities by most development and health indicators. Society in these districts is still feudal, with a high concentration of landless agricultural labourers working as bonded labour (Kamaiya) or seasonal agricultural labour (Haliya). On the other hand, in the eastern Terai cities the level of development is to some extent comparable to that of the Nepalese capital. 


\section{A history of forests politics in the Terai: a case of equity or ecology? ${ }^{13}$}

Because the equity and ecological issues in Terai forestry cannot be understood in an historical and socio-political vacuum, I will now provide a brief overview of the socio-political and environmental history of the Terai. It will be clear from the following discussion that in the past the state and ruling elites remained the major - and sometimes the only - beneficiaries of the Terai forests, exploiting them disproportionately for various purposes. Nepali rulers used the forests to generate revenue from the exploitation of their natural resources and establish agricultural areas in them to pacify and coopt political rivals. Some of the revenues were used to maintain the large army the rulers needed to deal with rebellion, treachery and uprisings. A closer look into the political economy of Nepal from an historical perspective suggests that only a few ruling elites at the centre, and the local elites that arose subsequently under the impulse of the country's autocratic political system and feudal social structure, were allowed to benefit from the Terai forests.

During the eighteenth and nineteenth centuries, the surplus from agricultural production and forestry was largely channelled toward the maintenance of a military establishment to support territorial expansion after the unification of Nepal. ${ }^{14}$ During the Rana period (1846-1951), revenues from the Terai forests were used for the maintenance of the aristocracy and state bureaucracy. The oligarchic regimes of the Shahs and Ranas before 1951 had always depended on the select classes of society to maintain their authority, but the

${ }^{13}$ For earlier critical and analytical histories of Nepalese forestry, see, among others, Y.B. Malla, "Changing Policies and the Persistence of Patron-client Relations in Nepal", in Environmental History, 6, 2, 2001, pp. 287-307. A.P. Gautam, G.P. Shivakoti, E.L. Webb, "A Review of Forest Policies, Institutions, and Changes in the Resource Condition in Nepal", in International Forestry Review, 6, 2, 2004, pp. 136-148. Given the dominant focus of previous works on community forestry in the mid-hills of Nepal, I preferred to concentrate my analysis on the less studied but equally interesting, as well as contested and complicated, case of Terai forestry.

${ }^{14}$ M.C. Regmi, Landownership in Nepal, Adroit Publishers, Delhi 1977, pp. 190 ff. 
exploitation of forests by a privileged few continued even after 1951, even when the forestry sector came under the management of the Forest Department. The legacy of this intense exploitation of the Terai forests benefiting only the state and certain privileged classes has endured to this day, despite the evolution of forest management practices towards community forestry in most of the hills of Nepal.

The major turning points in the history of Nepal and the subsequent changes in forestry policy suggest three distinct phases in the history of forest exploitation and management in the Terai. Throughout this evolution, however, Terai forestry has remained inequitable and unsustainable.

\section{8-1951 (past history)}

Before the establishment of the Gorkha kingdom (pre-1768), Nepal was divided into many small principalities across the country, including the Terai region, often at war with one another. The frequent fighting distracted these principalities from setting up any form of sustained and organized extraction of forest resources from the Terai. After the Gorkha ruler Prithvi Narayan Shah conquered Kathmandu and laid the foundations for a unified kingdom in 1768, he continued to pursue his ambition by conquering most of the hill areas and parts of the Terai. During the Gorkha kingdom phase, the forests in the Terai were still retained as a form of natural defensive barrier against enemy aggression, mainly by pre-colonial Indian rulers and British invaders. To maintain the integrity of the Terai forests as a natural defence, various royal decrees banning settlements and cultivation were issued, notably in 1817,1824 and $1826 .{ }^{15}$ While forests in the Terai were protected for military security until the late nineteenth century, in the hills incentives were given to convert forests to agriculture in order to reap land taxes at least as far back as the sixteenth century.

After the unification of Nepal, the ruling Shah monarchs began granting large tracts of land (including some forestland in the Terai)

${ }^{15}$ J. Guthman, "Representing Crisis: The Theory of Himalayan Environmental Degradation and the Project of Development in Post-Rana Nepal", in Development and Change, 28, 1997, pp. 45-69. 
with lavish tax exemptions, thus benefiting select classes of people and political favourites. This measure, a tactic also used by the Ranas, was a means for the rulers to consolidate their power. In addition, Terai forests provided a source of revenue to maintain the increasing military presence required for the ongoing geographical expansion of the kingdom, as well as providing opportunities for agricultural expansion into some selected areas after forest clearing.

From 1846 to 1951 Nepal was run by hereditary chief ministers, the Ranas, who superseded the monarchy and pursued a deliberate policy of stagnation and isolation, building grand palaces for themselves while investing little in public works. The Ranas exploited the Terai forests as a major resource to draw upon when they needed to reward their trusted adherents or conciliate their political opponents. Certain tracts of land in the region (both cultivated and forested) were granted on temporary or permanent bases in the form of Jagir (land assigned to a state servant temporarily in lieu of salary), Birta (permanent tax-free landholdings) or Guthi (revenue-free landholdings for religious bodies). The majority of land holdings in the Terai were appropriated as Birta by the Ranas themselves. It was estimated that by the first half of the twentieth century the ruling classes in Nepal possessed almost half of the cultivated land, with three leading Rana families alone owning as much as $92 \mathrm{~km}^{2}$ of land. ${ }^{16}$

The Ranas sought to strengthen their control over the Terai by introducing a new category of officials known as Jimidars to collect revenues from land and crops. The Jimidars were predominantly men from the hills. Madhesis were never a part of the inner core of the state's administrative and political structure. The Jimidars, who controlled local peasants and maintained close ties with the Ranas at the centre, later became locally-based elites and long remained the main bastions of Rana rule in Nepal. The Ranas also encouraged hill people (Pahadiyas) to migrate into the Terai. However, the plains being an alien environment, where the unbearable heat and endemic malaria made migration an even less attractive prospect, it is the Jimidars who helped to bring the majority of cultivators into the Terai from India.

${ }^{16}$ K. Ghimire, Forest or Farm: The Politics of Poverty and Land Hunger in Nepal, Manohar Publishers and Distributors, Delhi 1998, pp. 33-34. 
The Ranas were thus able to open up new forested land for agricultural expansion and generated increasing revenues from land taxes and agricultural surplus for the ruling class and the military.

The Terai forests were also exploited to supply timber to India. As British India expanded railway systems across the states of Bihar and Uttar Pradesh, the Terai became a ready supplier of hardwood for railway sleepers. In an effort to appease British colonialists and thereby retain their grip on power, the Ranas set aside some areas of the Terai forests as natural reserves, even taking their British counterparts on hunting parties there, besides sending massive exports of timber and agricultural surpluses to British India. These natural reserves were therefore initially developed to protect game in order to satisfy the recreational interests of the aristocracy, rather than for wildlife or forest conservation per se. ${ }^{17}$ Parts of Chitwan and Bardia (both in Terai) that were originally designated as reserves for trophyhunting by the Ranas now remain as examples of biodiversity conservation, under their present designations of Bardia National Park and Chitwan National Park.

\section{1- 1990 (recent history)}

The second phase of forests politics in Nepal began in 1951, after the end of the Rana regime. ${ }^{18}$ With a new political system in place, achieving social and economic equity became the guiding principle of state policy, for the first time in the country's history. The political change saw some major government reforms in two sectors, land and forestry, which are important pillars of Nepal's social and economic life. The Birta, Jagir and Jimidar forms of landownership were abolished. Through the Private Forest Nationalisation Act (1957), most forests that had previously been held as personal property by the Ranas

${ }^{17}$ K. Ghimire, Forest or Farm: The Politics of Poverty and Land Hunger in Nepal, Manohar Publishers and Distributors, Delhi 1998.

${ }^{18}$ After the end of Rana rule, the sovereignty of the monarchy was restored and anti-Rana rebels in the Nepali Congress Party formed the government. Nepal entered the international stage with membership of the United Nations in 1955 followed by the establishment of diplomatic relationships with Western countries. 
and local elites were nationalised and brought under state control. The nationalisation was endorsed by the first elected Nepali Congress government (1959-60). However, the short-term impact of the introduction of centralised management of forests proved negative, since some forests in the Terai were cleared by private individuals and rapidly converted into agricultural land to evade the new provision. Moreover, the recently established Forest Department was unable to act and enforce rules effectively, mainly due to inefficiency, staff shortages, a harsh approach to dealing with local users, and endemic corruption.

In the post-1951 period, the export of Terai timber to India remained an important source of revenue. Emphasis was placed on the exploitation of Sal forests. The nationalisation of forests in Terai provided the government with a major source of income. The role of the state as the major stakeholder in Terai forestry was further consolidated after the 1960 takeover by King Mahendra, who abruptly dismissed the popularly elected Nepali Congress and took direct control of government under the party-less Panchayat system, which lasted for 30 years until its fall in 1990. During the Panchayat period, the introduction of controversial resettlement projects in the Terai from the mid-1960s onwards was closely linked to opportunities for timber extraction for sale to India. As a result, there was massive deforestation in the region, which lost 25 per cent of its forest cover in just fourteen years (1964-1978). ${ }^{19}$ Another driving factor was the proximity of the Indian timber market, which to this day has remained a contributory factor in Terai deforestation. Although only limited timber sales were licensed legally, considerable quantities of wood and timber were smuggled into India by various routes, including rivers and roads. Moreover, the construction of the EastWest Highway - the only major highway in Nepal linking urban centres other than Kathmandu with the Terai - made the felling of trees for commercial timber more profitable as road transportation became easier. However, as the price of wood and timber across the border in India was considerably higher than in Nepal, the Indian market remained attractive.

${ }^{19} \mathrm{~J}$. Whelpton, A History of Nepal, Cambridge University Press, Cambridge 2005, pp. 122-123. 
By the 1950s, the eradication of malaria, increasing population pressure in the hills, and the opening of previously inaccessible areas made the Terai plains more attractive for new settlement. Due to its high production potential and the greater economic prospects it offered, Terai land became one of the most sought after commodities. Many members of the ruling elites and the royal family as well as rich and powerful locals strove to gain possession of both cultivated and forested land in the region. In the 1950s and 1960s, vast numbers of migrants moved into the central and eastern Terai. From the 1970s onwards, the western Terai also became an important destination due to increased land availability from forest clearance.

The political context in which such migration took place is worth mentioning here. Most of the Terai inhabitants (Madhesis with Indian roots) were used to the multi-party democracy and liberal policies across the border. As new migrants they felt constrained by the new repressive political climate in Nepal. As a result, discontent and dissidence grew more in the Terai than elsewhere in Nepal. In fact, popular opposition to the Rana regime had originated and grown in the eastern Terai town of Biratnagar in the 1940s and later in other urban pockets of the Terai and Kathmandu. Similarly, the Terai saw much of the growing opposition to royal rule under the Panchayat system. Hence, the state encouraged (both officially and unofficially) the Pahadiyas - who were seen as more loyal to the Hindu monarch and the Panchayat system - to migrate and encroach upon forest areas with new settlements and dwellings, in an effort to politically integrate the Terai people into the Panchayat system. For the same reason, even repatriates, mostly Gurkhas (Nepalese of hill origin serving in the British and Indian armies), were encouraged to return with promises of land in the Terai.

When official resettlement plans were initiated in 1955, they targeted ordinary farmers, who were allotted some land. However, despite a ban on sale for, initially, three years, many plots were sold to the members of the Kathmandu elite, many of whom thus became absentee landlords. ${ }^{20}$ Large numbers of Sukumbasis (landless squat-

${ }^{20} \mathrm{~J}$. Whelpton, A History of Nepal, Cambridge University Press, Cambridge 2005, pp. 140-141. 
ters) also cleared forests for settlements and cultivation without official authorisation, although their 'illegal' action usually went unchecked. The reluctance to act against the Sukumbasis was due to the covert selfinterest of local politicians, for whom the Sukumbasis represented vote banks. Local forestry officials also used these 'illegal' settlers to raise money for themselves, in addition to the money they were already generating from sales of wood and timber from settlement areas.

To understand the pressures on the Terai forests from migration and the resulting forest/land conflicts, it is worth recalling the situation of the peasantry during this period. Most peasants were landless or owned very small plots of land, whereas a few large landholders owned sizable farms. Due to this unequal land-holding structure, in the 1950s and 1960s many Terai peasants were paying up to 80 per cent of their main crop as rent. The 1964 Land Reform Act set a threshold of 50 per cent of the gross product for land rent (later amended to 50 per cent of the main crop), which still made the position of tenants insecure if the crop failed, as they were also required to bear the costs of cultivation. ${ }^{21}$ Successive political leaders at various times have promised to reform the landholding structure by reducing the amount of land per individual owner. However, no real changes in this direction have been made so far. ${ }^{22}$

The Panchayat system slogan Hariyo Ban Nepalko Dhan ('Green forests are Nepal's wealth'), believed to have been coined by King Mahendra and proudly spread by the Forest Department through national radio and pamphlets, stressed the importance of forests for the state and the Nepalese economy. However, the general perception of the common people was that the state and ruling elites benefited disproportionately from the forestry sector (which was mostly concentrated in the Terai forests). The same phrase was ridiculed by the

${ }^{21}$ K. Ghimire, Forest or Farm: The Politics of Poverty and Land Hunger in Nepal, Manohar Publishers and Distributors, Delhi 1998, pp. 70-77.

${ }^{22}$ For example, efforts to regulate land started as early as Chandra Shumsher's time during Rana rule. Land reform efforts continued at various times, notably during the Nepali Congress government (1957), King Mahendra's direct rule (1964), and the Sher Bahadur Deuba's government (2001-2002). After 2006 the issue has cropped up once again, although with no significant progress. 
public as Hariyo Ban Mahendra Sarkarko Dhan ('Green forests are King Mahendra's wealth'). Furthermore, alleged reports of the handover of large numbers of felling permits by Surya Bahadur Thapa's administration to finance the Panchayat campaign against the demand for multi-party democracy in the 1980 referendum contributed to a generally negative popular perception of the state's role in the control of the Terai forests. Additionally, there were cases of corruption in the Timber Corporation of Nepal, which was formed in 1959 as a government agency with a monopoly for extracting and selling timber.

During the 1970s, while concern for environmental protection and conservation was mounting due to the growing debate on the 'Theory of Himalayan Degradation', ${ }^{23}$ forest protection measures were only serving the private interests of the senior bureaucrats and forestry officials involved in the management and commercial exploitation of forests. The 1950s trend towards a nationalisation of forests was reversed in 1978, when community ownership and management of forests was recognised and established in the hills in an effort to save the declining forests and reduce the risk of 'Himalayan degradation'. ${ }^{24}$ In the Terai, however, the state retained its control of forests; indeed, this control assumed a more coercive form when more national parks were established for conservation purposes. This protectionist approach, however, rather than casting a positive light on the state as a guardian of nature, reinforced the belief held by many Nepalese that the state wanted to remain the sole exploiter of the Terai forests.

${ }^{23}$ The theory claimed that the Himalayas and its southern plains (i.e. the Terai) were heading towards an environmental catastrophe of epic proportions due to rapid population growth (2-3 per cent per year), intensification of agriculture, overgrazing, and massive deforestation in the Nepal hills. See E.P. Eckholm, "The Deterioration of Mountain Environments", in Science, 189, 1975, pp. 764-770. This narrative of Himalayan degradation based on neo-Malthusian theory was later challenged and an alternative body of literature emerged over the years focussing on socio-economic and political approaches to explain environmental change in Nepal. See for example P. Blaikie, The Political Economy of Soil Erosion in Developing Countries, Longman, London 1985. J. Ives, B. Messerli, The Himalayan Dilemma: Reconciling Development and Conservation, Routledge, London 1989.

${ }^{24}$ D.A. Gilmour, R.J. Fisher, Villagers, Forest and Foresters: The Philosophy, Process and Practice of Community Forestry in Nepal, Sahayogi Press, Kathmandu 1991. 


\section{Post-1990 (present forest policies and practices)}

It is now evident from historical accounts of past forest policies that continued state control, a revenue-oriented approach to forestry, commercial considerations and the lack of proper forest management policies have all contributed to the rapid transformation and degradation of the Terai forests. Besides these historically inherited features, since 1990 political instability and weakened policing have become contributory factors in this degradation.

The post-1990 period of multi-party democracy in Nepal (the period, that is, that followed the first people's movement or Janandolan I) was characterised by factionalised politics with frequent changes of government. During the 1990-1991 transition period from three decades of Panchayat rule to a multi-party system, there was considerable illegal logging and deforestation in the Terai forests. Thereafter, political instability and crisis in the country, mainly fuelled by the Maoists' rebellion in the form of a decade-long 'people's war' (1996-2006), and the royal takeovers of 2002 and 2005 also took a heavy toll on the forests. ${ }^{25}$ Due to increasing political instability, many districts of the Terai saw a sharp rise in logging. In the forests in the protected areas and national parks of the Terai, illegal logging and wildlife poaching became common. Although park boundaries were guarded by the Nepalese Army, there were increasing instances of conflicts between the parks and local people. After 2000, the army was withdrawn from many park boundaries and mobilized to counter the increase in Maoist violence. This had a negative effect on conservation of protected areas, with armed poachers and loggers becoming more active.

Since the political change of 2006, which was brought about by massive protests against royal rule in the form of the second people's movement (Janandolan II), once again an increasing trend towards the degradation of Terai forests began, and has gone one to this day due to the transient nature of national politics in Nepal. Organized illegal

${ }^{25}$ P. Satyal Pravat, Forestry Sector in Nepal: A Country Profile Report, Forests Monitor, Cambridge 2004, pp. 11-12. 
logging and massive tree felling by illegal contractors and traders have increased in the Terai, often with the direct or indirect support of local forest officials, senior members of local forest user groups, and sometimes cadres and officials of the political parties in power.

While Terai forestry has been a victim of volatile national politics, forests in the Terai have historically been used as a 'cash cow' to meet the vested interests of political parties and bureaucrats. As a result, the Forest Department and Forest Ministry still suffer from the historical legacy of a corrupted image due to their increasing involvement in the politicisation of the Terai forests and the misuse of revenues for financial and political purposes. ${ }^{26}$ This was a common practice during the authoritarian rule of the Panchayat era, but continued into the 1990s with alleged reports of the personal involvement of forest ministers in abuse of authority and malpractice. Some large illegal concessions were handed out to local contractors to win political favours and elections, as well as make quick money. (Somewhat ironically, the office of Forest Ministry was usually assigned to a Terai minister.) Although there was no reported case of granting concession rights to Western multinational logging companies (a lucrative malpractice indulged in by local politicians in many developing countries), one such attempt was resisted with huge public and media protests. ${ }^{27}$

In the country's fluid political situation, another factor in the mismanagement of Terai forests was the unwillingness of the forest bureaucracy to respond to the new political context. Despite reinstatement of multiparty democracy in 1990, the introduction of a

${ }^{26}$ In the interim cabinet formed after 2006, the Ministry of Forests and Soil Conservation was under a Maoist minister, Matrika Yadav, who publicly acknowledged on several occasions that the Forest Ministry was still plagued with endemic corruption (The Himalayan Times, 18 June 2007). In informal conversations with the present writer, this claim was endorsed by at least two ex-forest ministers. During my field study, many low-level staff in the districts such as forest guards and rangers also had several anecdotal accounts of corrupt practices within their department.

${ }^{27}$ As a result, in 1996 the government's plan to grant concession rights to a Finnish company, Enso International, had to be dropped. See N.K. Shrestha, C. Britt, "Another Balanced Overview: An Equation with More than Money", in FTTP Newsletter No. 32-33, Forest Trees and People Programme, Swedish University of Agriculture Sciences, Uppsala 1997. 
decentralized forest policy, increasing political awareness at the local level, and the emergence of civil society in the forestry sector (in the form of forest user groups and their networks, as well as various forestry NGOs), technocratic domination of forest policy continued in Nepal, most particularly in the Terai forests. The forest bureaucracy in Nepal was founded on a notion of forestry emphasizing centralised management of timber for state interests with foresters and rangers trained in traditional scientific forestry adapted from the colonial education system of India. Due to this long historical schooling and organization culture, forest bureaucracy in Nepal is still dominated by technocratic rationality over deliberative practice (in the form of dialogue, debate and discussion) and is resistant to reflective change and power shifting. ${ }^{28}$ The reluctance of the forest bureaucracy to radical change was not, however, unexpected given the reluctance to reform strategic areas of national development exhibited by successive post- 1990 governments. This inertia and resistance to change was contrary to the spirit and aspirations of Janandolan I and still works against the transformation of Terai forest governance after Janandolan II.

The centralized character of the Nepali state was particularly evident in its management of Terai forestry. The state maintained control of most forest areas in the Terai, and held a monopoly on timber harvesting and marketing through its subsidiary, the Timber Corporation of Nepal. Although the Corporation was deprived of its dominating position in 2000, the sale of timber is still far from being conducted in a free market regime. There were some attempts by subsequent forest policies to respond both to the changed internal political context and to external pressure in favour of participatory governance of natural resources, but due to the state's contradictory stance these measures did not result in any fundamental changes in Terai forestry. While support for the community forestry programme in the hills was legalised and institutionalised through enforcement of the Forest Act (1993) and Forest Regulations (1995), most of the

${ }^{28}$ B. Pokharel, H. Ojha, Community Forestry in Nepal: A Platform for Public Deliberations or Technocratic Hegemony?, Discussion Paper, Forest Action, Kathmandu 2006. 
Terai forests remained under government control. Although the 1993 Forest Act did not apply any restrictions for the handover of forests by the government to local communities for community management anywhere in Nepal, including the Terai, the controversial Revised Forestry Sector Policy of 2000, introduced amidst oppositions from community forestry activists and forestry NGOs, restricts the handover as 'community forests' in Terrai to barren land, shrub land and isolated patches of degraded land, ${ }^{29}$ and concomitantly stipulates that large continuous areas of productive forests in the Terai will remain under the centralized control of the state, in many cases under the surveillance of the Nepal Army and armed forest guards; although in some cases the collaborative management of these areas is envisaged. The Revised Forestry Sector Policy of 2000 does envision collaborative forest management in the Terai as an alternative to the dominant model of community forestry in the hills, including the distribution of benefits and revenues among the central government, local government and local users (although inequitably, with 75 per cent of the revenues flowing to the central treasury while only 25 per cent remains with the local government and users). The revised 2000 policy also aims to solve the critical issue of inclusion of distant users, mainly Madhesis, which the current policy and practices of the hill model of community forestry does not address. However, opponents, mainly community forestry activists, see this policy merely as a tactic to consolidate government control over forest revenue. These arguments and counter-arguments with regard to forestry policy in the Terai have turned from polarized conceptual debates into field-level conflicts. As a result, neither the collaborative nor the community forestry models have gathered momentum in the Terai.

I have argued that forest management policy in the Terai has been a complex, hotly debated and politically controversial issue in Nepal. While many NGOs, including the influential FECOFUN (Federation of Community Forestry User Groups) with more than

${ }^{29}$ See Nepal Government, Forest Act 1993 and Forest Regulation 1995, Ministry of Forests and Soil Conservation, Kathmandu 1995. Nepal Government, Revised Forestry Sector Policy 2000, Ministry of Forests and Soil Conservation, Kathmandu 2000. 
14,000 forest-user group members across the country, want the handover of the Terai forests for community management, the state wants to retain them under its control or at least under collaborative management. The position of the multilateral and bilateral donors active in the Terai forests has also been divided, with some directly or indirectly supporting community management (mainly CAREInternational and the Department for International DevelopmentDFID) and others supporting the government's protectionist approach for biodiversity conservation (notably the SNV-Netherlands Development Organization and the World Wild Fund for NatureWWF). FECOFUN and community forestry activists accuse the government of using its revenue-oriented policy of collaborative management to maintain its control over the nation's valuable forest resources. They make the case that those forests that were handed over as community forests before the state developed its policy of collaborative management are on the whole protected and managed much better than under earlier government control, and in several cases benefit the poorest groups.

However, as advocated by many community forestry activists, there are some practical challenges to translating the success of community forestry as practiced in the hills to the Terai. Unlike the hills, the Terai has no history of community-based collective action, let alone a history of community forest management; hence, one fundamental challenge is to create a new organization of community forest user groups. Larger forest sizes, recent settlements, problems in identifying and organizing user groups, the existence of attractive timber markets nearby, together with widespread and organized illegal timber felling, all create additional obstacles to community management in this region. The concerns about equity between proximate users (mainly Pahadiyas) and distant users (mainly Madhesis) also presents a complex and pressing issue in the case of the Terai, as most forests lie far away from the settlements, unlike the hill community forests where local communities live near forest patches.

Due to these problems and the Forest Department's desire to maintain its control over high-revenue forests, community forestry has been widespread only in the hills, while in the Terai its introduction and success has been more problematic. The handover process 
has been slow and has been stalling for the last few years (as of October 2006, out of a total of 14,337 community forest user groups formed across Nepal, only 1,330 are in the Terai). ${ }^{30}$ The policy of the government and some major donors to enforce collaborative management models for most Terai forests has encountered active resistance and opposition from the community forestry lobby. Due to this, no further progress has been possible in terms of forest governance reform, as the government has been unable to achieve much without active support from the relevant stakeholders.

This latest phase of forest politics in the Terai originates from conflicts of interests between the various stakeholders and highlights the complicated case of Terai forestry. In some way, the present conflict can be understood as the perpetuation and reproduction of historically unequal power relations and the inequitable distribution of costs and benefits from the forestry sector in the Terai. The historical legacy of state forest policies, the superseding of local subsistence needs by national commercial interests, and the forest bureaucracy's tacit support of the status quo have all acted to hinder forest governance reforms in the Terai. In this context, it is essential to acknowledge and learn from past mistakes, and recognise that the continued centralised control of Terai forestry is reproducing historical social, economic and political inequalities; indeed, the present state of affairs, with contested and divisive conflicts between the community forestry and collaborative forest management lobbies, has further aggravated it.

With Terai forestry now in a state of stagnation and in the context of Nepal's rapidly changing political landscape, potentially heading towards a federal republican structure, there is an increasing realisation and consensus among various stakeholders that urgent intervention is needed to introduce appropriate institutional mechanisms to benefit the poor and marginalised while ensuring the long term sustainable management of the forest resource. Yet this immediately leads to the question of how such reforms can be achieved, and by whom. Based on my exploration of the history of forest politics in the Terai, my argument is that recognising and reflecting upon the

${ }^{30}$ Nepal Government, Database of the Community Forest User Groups in Nepal, Department of Forests, Kathmandu 2006. 
historical mistakes of past policies might help to answer this question. Only by understanding the historical context can the future course of forest politics in Nepal be guided towards the needs of local communities and the exigencies of the long term sustainable management of the resource.

\section{Conclusion}

This paper began by outlining and discussing the historical roots of the socio-economic inequalities that have informed forest politics in the Terai and which continue to influence current forestry policy and practice in the region. The dominance and monopoly of the state in the forestry sector has resulted in an unequal distribution of the benefits flowing from the forest sector, creating the historical conditions for inequity in Terai forestry. Only relatively few people, particularly those who dominate the state machinery and power politics, have benefited from Terai forestry, whereas ordinary Nepalese - most of whom depend on farms and forests for their survival and livelihood - have been denied an equitable share of the benefits.

Even today, the legacy of inequitable distribution of the benefits from Terai forestry remains, shaping and influencing the forest management and governance policies of the state in the region. The revenue from forests continues to contribute a significant portion of Nepalese national income, which explains why the state has insisted on retaining its major stake in forests. This has had consequences for the ecology of the region, as the main motive of the state has been to retain its monopoly over the region's valuable forests for economic reasons, rather than to preserve their ecological integrity. An historical overview of Nepal's political economy also makes it clear that old power relationships remain more or less intact in all strata of Nepalese society, and this is also true of the forestry sector. Over the last three centuries, the practice of exploitation of Terai forestry has been institutionalized firmly within the state bureaucracy. As a result the question of how to change this power structure in order to create the conditions for equity and ecological sustainability has become an important issue.

If managed efficiently, the forests of Terai have the potential to boost the local economy, while also generating significant revenue 
for Nepal as a whole. However, given the consequences of years of political instability and the continued reluctance of the state to engage in democratic, participatory and inclusive governance, it has yet to be seen whether transparent, accountable and sustainable Terai forestry can be achieved in the near future. If the state retains its leading role, given its commercial interest in timber extraction and its reluctance to promote a governance framework involving all stakeholders, there is a risk that Nepal will squander the Terai forest resources with no long-term benefit to the country and its people.

The future shape and role of Terai forestry will need to be consistent with the wider societal and political changes of the country towards peace, justice, inclusive democracy and equitable development. In the post-2006 Janandolan II period, most prominently after the election of a constituent assembly to write a new constitution, the latest political discourse is of building a 'new Nepal' organised along federal and multicultural lines, a decentralised, inclusive and just nation rather than a unicultural, centralized one. If Terai forestry is to cohere with this vision it will require a significantly altered policy framework and a concomitant shift in the historical positions, power and roles of the state and the Forest Ministry. If consensual solutions are to be found, it will also require a restructuring and democratisation of policy processes with an increased emphasis on more open and deliberative dialogues between the various stakeholders of Terai forestry.

There are no easy answers to what model might be appropriate for the sustainable management of the Terai forests. The opening of more forests to community management and a modification of the current institutional framework of community forestry so as to include distant users might be one option. Another option might be to modify the collaborative forest management model by introducing further devolution of power and control and increased representation and participation of communities, followed by legislative changes and encouragement for affirmative action to include poor and disadvantaged groups. It might also be the case that new solutions can be found beyond the limited options of community and collaborative management, in an innovative management model in tune with the federal republican structure of the country in the new 
constitution. My contention is that only through constructive dialogue and vigorous discourse can we find an appropriate way that could herald the beginning of a new phase in the forest history of the Terai, finally fulfilling aspirations to a just, transparent, accountable, and sustainable forest governance in the region.

In conclusion, an observation can be made on the global relevance and importance of this case study, as the research and analysis discussed in this paper can provide useful insights in assessing similar cases elsewhere. Given the unfortunate fact that there are other regions of the world where very serious conflicts are in course between communities and forest users and the state and/or local elites over the ownership and management of forests, the ideas and experience gained from the investigation of the case of the Terai forests could help to improve our understanding of such conflicts worldwide, most particularly in the developing world. In many developing world contexts we find similar debates on forestry policy, with polarised opinions on who should manage the local forests. There remain similar ambiguities, dilemmas and reluctance in the forest administrations of many countries, and many agrarian political economies share similar local structural inequalities preventing the poor and disadvantaged groups from effectively voicing and defending their resource interests and claims. 